Year-to-year variation in carabid beetle (Coleoptera, Carabidae) assemblages on the Åland Islands, south-west Finland

Kotze, D.J.

Blackwell

2002

Kotze, D.J. and Niemelä, J. 2002. Year-to-year variation in carabid beetle (Coleoptera,

Carabidae) assemblages on the Åland Islands, south-west Finland. Journal of Biogeography 29: 375-386.

http://hdl.handle.net/1975/311

Downloaded from Helda, University of Helsinki institutional repository.

This is an electronic reprint of the original article.

This reprint may differ from the original in pagination and typographic detail.

Please cite the original version. 


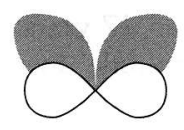

\title{
Year-to-year variation in carabid beetle (Coleoptera, Carabidae) assemblages on the Alland Islands, south-west Finland
}

D. Johan Kotze and Jari Niemelä Department of Ecology and Systematics, Division of Population Biology, University of Helsinki, Helsinki, Finland

\begin{abstract}
Aims (1) To investigate changes in structure of carabid assemblages between sites on the main island of Aland and five small nearby islands between 1982 and 1999. (2) To determine whether island differences observed in one year is mirrored in another one. (3) To examine changes in abundance levels of individual carabid species on these islands since 1982. (4) To compare the proportion of flightless species on the main island of Aland with those on the small islands.
\end{abstract}

Location Islands in the Baltic Sea, Finland; the main island of Aland (90,000 ha) and five small, nearby islands (8-29 ha).

Methods Carabid beetles were collected, using pitfall traps, during 4 years $(1982,1987$, 1988 and 1999). Sampling took place in moist, spruce-dominated, lush forest patches.

Results Overall, 12,127 individuals representing forty-six carabid species were collected; forty-one species (8580 individuals) on the main island of Åland, and thirty-one species (3547 individuals) on the small islands. Carabid assemblage structure, measured using ordination techniques, was consistently and significantly different between the main island and the small island sites. Carabid assemblage structure and abundances of individual species did change significantly between years, possibly because of a combination of climatological and habitat changes in the Aland archipelago. The six most abundant species collected on the small islands, and the three most abundant species overall, were all short-winged. Furthermore, the small islands had a higher proportion and number of short-winged species compared with the main island of Aland.

Main conclusions Carabid assemblage structure was significantly different between the main island and the small islands in all years sampled, indicating that single-year studies are sufficient to demonstrate differences in carabid assemblages on Baltic islands. Small islands host a non-random proportion of species pools available on the main island of Alland and mainland Finland. It appears that dispersal to islands in the Baltic Sea is easy for carabid beetles of all wing forms, but that short-winged species are more successful colonizers.

\section{Keywords}

Baltic Sea islands, carabid beetles, dispersal ability, main island-small island comparison, year-to-year variation. 


\section{INTRODUCTION}

Insect populations fluctuate between years, the changes in population sizes being often several orders of magnitude (Wolda, 1978, 1992; Den Boer, 1981). The mechanisms causing this pattern are not completely understood and many explanations have been proposed (Price, 1984). Furthermore, for many insect taxa, for instance carabid beetles, there are very few studies where sampling has continued over several years (Desender, 1996), making longterm studies particularly important in answering questions about year-to-year population dynamics, community dynamics and the importance of short-term conservation recommendations. Perhaps more importantly, long-term studies can distinguish gradual trends over time from short-term noisy fluctuations (Di Castri et al., 1992).

In carabids, environmental conditions, such as weather, have been regarded as decisive for population fluctuations (Baars \& Van Dijk, 1984a; Hengeveld, 1985). For instance, carabid larvae are very specific in their demands for suitable climatic conditions (Thiele, 1977). Thus, it may be expected that weather conditions varying between years affect carabid populations. Also, interspecific interactions, such as competition for food, are assumed to affect carabid populations (Lenski, 1982, 1984; Baars \& Van Dijk, 1984b; Loreau, 1986), although interspecific competition has been considered to be of minor significance as compared with abiotic factors (Niemelä, 1993). Regardless of the causes of population fluctuations, the fact that populations vary between years make conclusions on the spatial distribution of species based on a 'snapshot' view from 1 year less reliable than data covering several years.

Islands are useful 'ecological laboratories' and many questions of ecology can be studied by comparing island faunas with those on the nearby mainland (Haila, 1990; Kotze et al., 2000). Islands in the Baltic Sea are unique because inter-island distances are generally small, salinity is low (see Ås, 1984), and annual seasonality is pronounced (Järvinen \& Ranta, 1987). Furthermore, there is a long history of research on many of these islands rendering them suitable for studies in population and community ecology and conservation (Niemelä et al., 1985; Järvinen \& Ranta, 1987; Ås et al., 1997; Nieminen \& Hanski, 1998; Saccheri et al., 1998).

For example, in terms of carabid beetle wing form, islands off the coasts of Finland and Sweden host - contrary to expectation - a significantly higher proportion of shortwinged or wingless carabid species compared with their nearest mainland provinces (Ås, 1984; Kotze et al., 2000). Obviously, these short-winged species cannot fly from the mainland to the islands or between islands, but do get there in sufficient numbers to establish populations.

In this study we compared carabid samples taken with identical sampling design from the same sites on the main island of Åland and small, nearby islands in 4 years, spanning 17 years (1982, 1987, 1988 and 1999). The general observation in nature is that populations and assemblages are dynamic, and it is therefore expected that the carabid assemblages here will change over 17 years. Specific questions asked are: (1) By what magnitude does the carabid assemblage change over the 17 -year sampling period? (2) are differences observed between the main island and the small island carabid beetle assemblages in 1 year mirrored in the next, i.e. do the observed main island-small island distribution patterns of carabid species remain constant over the years? (3) following on from question 2, how reliable are the distribution patterns described on the basis of data from one year only, or in 1 year in general? (4) What are the proportions of flightless species vs. those able to fly on the islands compared with the main island of Aland?

Carabid beetles (Coleoptera, Carabidae) were used as study object not only because of their apparent flight ability differences, but also because the group is both ecologically and taxonomically well known, and occurs abundantly on Baltic islands (Lindroth, 1985, 1986; Niemelä, 1992, 1996).

\section{MATERIALS AND METHODS}

\section{Study area and carabid beetle sampling}

Carabid beetles were collected on the Aland Islands in SW Finland (about $60^{\circ} \mathrm{N}, 20^{\circ} \mathrm{E}$ ). Sampling was carried out in 4 years (1982, 1987, 1988 and 1999), in the same five moist, spruce-dominated lush forest patches on small (8-29 ha) islands (Slätskär, Äskskär, Ärtskär, Yttre Korsö and Inre Korsö), 2.5-3.8 km off the main island of Åland (area about $900 \mathrm{~km}^{2}$ ). Vegetation cover on these islands ranges between 20 and $70 \%$ of the island area (see Table 1 in Niemelä, 1988). Five patches of the same habitat type were studied on the main island of Aland. For more details on the location, vegetation and habitat structure of the sites, see Niemelä et al. (1985).

Mean yearly air temperature has increased slightly on Åland since 1970, more so during winter than summer months (Fig. 1). Yearly precipitation, however, has increased markedly since 1970 (Fig. 1).

Carabids were collected using fifteen pitfall traps (trap diameter $65 \mathrm{~mm}$, volume $170 \mathrm{~mm}$ ) per site. The fifteen traps were placed 4-5 $\mathrm{m}$ apart in three line transects of five traps each. A $50-\mathrm{mL}$ ethylene or propylene-glycol : water mixture $(1: 1)$ was used to preserve beetles in the traps. In 1982 and 1987 , carabids were sampled four times during each season with similar sampling effort (fifteen traps per site, 5-7 days per sampling period). The dates of the sampling periods were as follows: 22-27 May 1982 (20-27 May 1987), 24-29 June 1982 (24-30 June 1987), 22-27 July 1982 (28 July-3 August 1987), and 19-24 August 1982 (26 August-2 September 1987). Trapping was continuous in both 1988 and 1999 (fifteen traps per site), with sites being visited three times in each year. In 1988, sampling started on 23 May and ended on 28 August. In 1999, trapping started on 19 May and ended on 21 August.

Because of uneven sampling intensities between years, abundance values of each species were standardized to 100 trapping days as follows. For each carabid species, we 
Table I Repeated measures analysis of variance (ANOVA) to test for differences in carabid standardized abundance and rarefied species richness between the main island of Åland and the small island sites (the betweengroups factor) and between the 4 years sampled (the repeated-measures factor). The ability to fly (Flight) was entered as a covariate. Carabids were divided into those that have the potential of flight (macropterous and dimorphic species), and those that are flightless (brachypterous species)

\begin{tabular}{llllllr}
\hline Source of variation & $\begin{array}{l}\text { d.f. } \\
\text { effect }\end{array}$ & $\begin{array}{l}\text { MS } \\
\text { effect }\end{array}$ & $\begin{array}{l}\text { d.f. } \\
\text { error }\end{array}$ & $\begin{array}{l}\text { MS } \\
\text { error }\end{array}$ & $F$ & \multicolumn{1}{c}{$P$} \\
\hline Individuals (100 trapping days) & & & & & & \\
$\quad$ Main-small & 1 & 7.091 & 16 & 0.248 & 28.635 & $<0.001$ \\
Flight & 1 & 6.165 & 16 & 0.248 & 24.895 & $<0.001$ \\
Year & 3 & 0.326 & 48 & 0.041 & 7.895 & $<0.001$ \\
Main-small $\times$ flight & 1 & 1.032 & 16 & 0.248 & 4.166 & 0.058 \\
Main-small $\times$ year & 3 & 0.223 & 48 & 0.041 & 5.413 & 0.003 \\
Flight $\times$ year & 3 & 0.283 & 48 & 0.041 & 6.863 & $<0.001$ \\
Main-small $\times$ flight $\times$ year & 3 & 0.237 & 48 & 0.041 & 5.751 & 0.002 \\
Species $($ rarefied, $n=5)$ & & & & & & \\
Main-small & 1 & 0.737 & 16 & 0.247 & 2.988 & 0.103 \\
Flight & 1 & 10.672 & 16 & 0.247 & 43.250 & $<0.001$ \\
Year & 3 & 0.282 & 48 & 0.214 & 1.316 & 0.280 \\
Main-small $\times$ flight & 1 & 1.026 & 16 & 0.247 & 4.158 & 0.058 \\
Main-small $\times$ year & 3 & 0.126 & 48 & 0.214 & 0.589 & 0.625 \\
$\quad$ Flight $\times$ year & 3 & 0.071 & 48 & 0.214 & 0.332 & 0.802 \\
$\quad$ Main-small $\times$ flight $\times$ year & 3 & 0.617 & 48 & 0.214 & 2.881 & 0.045 \\
\hline
\end{tabular}

Main-small = Main island-small islands.

Standardized carabid abundance values (100 trapping days) were log-transformed to approximate normality. Rarefied species richness data $(n=5)$ were not transformed. Pterostichus niger was classified as a flightless species (see Lindroth, 1986). pooled the number of individuals collected at each site (fifteen traps), per year. Although trap number was similar between all sites, the periods over which sampling took place differed: twenty trapping days in 1982, twenty-six in 1987, ninety-seven in 1988 and ninety-four in 1999 (see above). Therefore, the site-specific abundance values were standardized to 100 trapping days in each year.

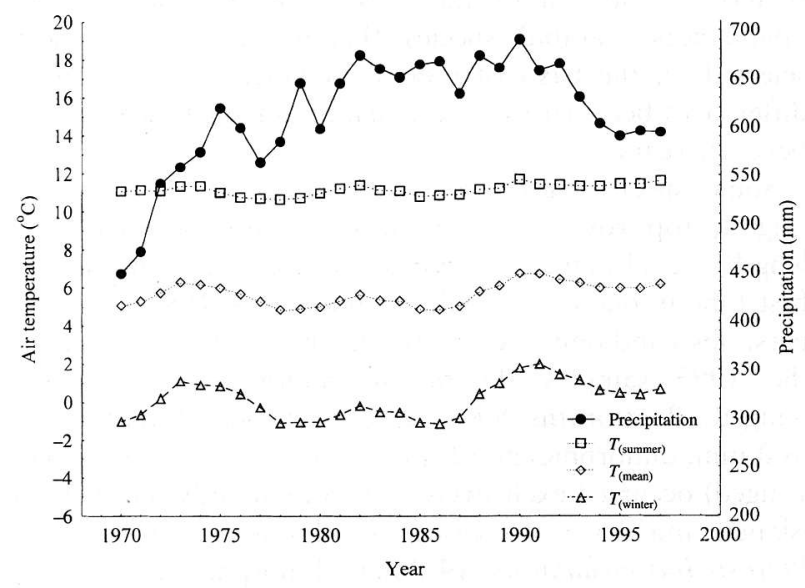

Figure I Main climatological indicators measured at Jomala $\left(60^{\circ} 07^{\prime} \mathrm{N} 19^{\circ} 54^{\prime} \mathrm{E}\right), \AA$ Aland, the closest meteorological station to the study sites (Meteorological Yearbook of Finland, 1968-99). Yearly precipitation, summer $\left(T_{\text {summer }}\right)$, mean $\left(T_{\text {mean }}\right)$ and winter $\left(T_{\text {winter }}\right)$ mean air temperatures since 1970 are shown. Points represent moving average values (calculated from 5 years; i.e. the moving average value for 1970 was calculated using values from 1968-72, etc.).

\section{Statistical analyses}

To study changes in carabid assemblages across the years and reliability of 1 year's sampling we used three analyses. First, species richness on the small islands was compared with that on the main island by constructing species accumulation curves for both the main island and the small island sites. Sampling order was randomized 100 times to eliminate sampling error and heterogeneity among the units sampled, and the mean and standard deviation of the number of species collected, $\mathrm{S}(n)$, was computed for each value of $n$ between one and twenty (five main island or small island sites $\times 4$ years) (Colwell $\&$ Coddington, 1994).

Secondly, a nonmetric multidimensional scaling (NMDS) ordination, using a Bray-Curtis triangular similarity matrix was used to construct a two-dimensional map of carabid assemblage changes (carabid abundance standardized to 100 trapping days, see above) between the main island and the small islands, and between years (Clarke, 1993). The main advantage of using NMDS is that it displays rank similarities between samples, considered a biologically relevant definition of similarity between samples (Clarke, 1993). To test for differences in carabid assemblage-structure between the main island and the small island sites and between years, an analysis of similarity test (ANOSIM), was used. Analysis of similarity test is a nonparametric permutation procedure, and it uses the rank similarity matrix underlying the ordination of samples (Clarke \& Green, 1988; Clarke, 1993). It is important to note that the ANOSIM was performed on a priori selected groups of samples, here the yearly main island and small island sites. This analysis was complemented by investigating the distribution patterns of 
individual species between the main island and the small islands, and between the years sampled.

Thirdly, a repeated measures ANOVA was used to test for differences in carabid abundance (carabid abundance standardized to 100 trapping days, see above) and species richness between the main island and the small islands (between-group factor) and between years (repeated measures factor). Species richness values per site were adjusted using rarefaction, which is a statistical method for estimating the number of species expected in a random subsample (here five individuals) drawn from a larger sample (Simberloff, 1978; Magurran, 1988). Visual inspection of the data (using normal probability plots) suggested that the abundance data should be log-transformed to approach normality. Rarefied species richness data did not need to be transformed.

To test the effect of flight ability on the incidence of carabid species on the main island vs. on the small islands, and between years, flight ability was included in each of the two ANOVA models described above (abundance and species richness) as a covariate. Carabids were grouped into those with the potential of flight (hind wings constantly macropterous, or dimorphic species with individuals having either non-functional or functional hind wings), and flightless species (hind wings constantly brachypterous) [beetle characteristics obtained from Lindroth $(1985,1986)]$. This design resulted in eighty sampling units per ANOVA test: carabid beetles collected at each site pooled into a capable of flight and flightless group, with forty sampling units per group (five main island sites $\times 4$ years, plus five small island sites $\times 4$ years).

\section{RESULTS}

\section{Carabid assemblage structure changes}

A total of 12,127 individuals representing forty-six carabid species were collected (Appendix 1). The three most abundant species accounted for $56.9 \%$ of the total catch. Trechus secalis was the numerically dominant species $(24.8 \%)$, followed by Patrobus atrorufus $(23.5 \%)$ and Pterostichus niger $(8.6 \%)$. Nineteen carabid species were represented by less than ten individuals. Species accumulation curves for both the main island and small island sites indicate that most of the carabid species occurring in the sites were eventually collected, and that the main island sites accumulated species quicker than did the small islands (Fig. 2). Furthermore, the total number of species on the main island (forty-one species) was higher than on the small islands (thirty-one).

According to the NMDS analysis, there was a statistically significant separation between the main island and the small island sites in terms of carabid assemblages (Fig. 3). The main island-small island separation of the sites and their clustering according to location on the small islands or on the main island is to a great extent caused by the relatively high abundance of four of the fifteen species collected only on the main island (Agonum livens, Carabus nemoralis, Leistus terminatus and P. melanarius, see Appendix 1). On the contrary, the five species not collected on the main island

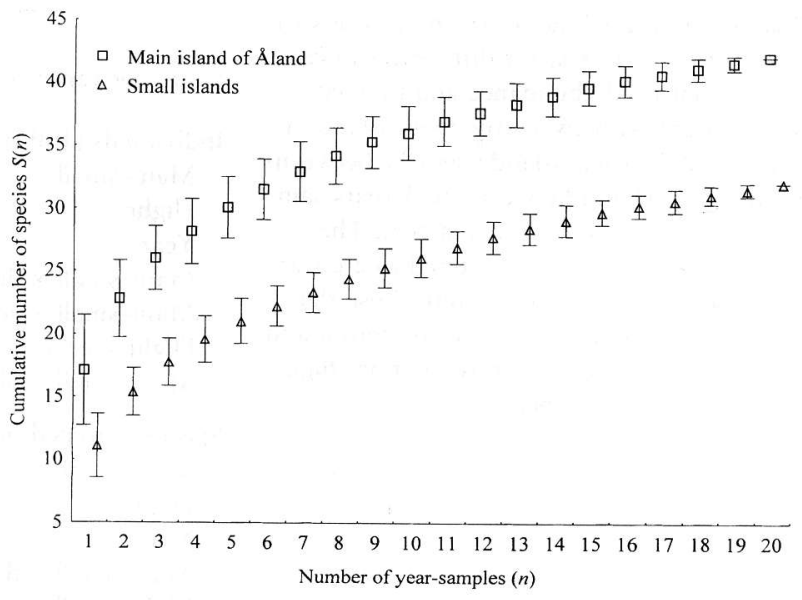

Figure 2 Species accumulation curves for main island and small island sites. Each point represents the mean of 100 randomizations of sample pooling order while the error bars are the corresponding standard deviations. The twenty points for the main island (or small island) curve represents the 'number of year-samples', i.e. 4 years $x$ five sites.

were only represented in singletons on the small islands (Appendix 1). Furthermore, assemblage structure also changed significantly from 1982 to 1999 for both the main island and small island fauna (Fig. 3), but the separation of the main island-small island sites remained. Therefore, samples taken during 1 year only would correctly depict the difference between the main island-small island carabid assemblages.

To further explore the possible reasons for the marked differences between the main island and the small island assemblages, and between years, we plotted the distribution patterns of sixteen of the most abundant (standardized abundances) carabid species (Fig. 4). The species were selected on the basis of their abundance and distribution differences between the main island and small islands, and between years.

Some species have occurred only on the main island (Fig. 4, top row). C. nemoralis, a large (average body length $=23.9 \mathrm{~mm}$ ), short-winged species was found for the first time in one of the main island sites in 1993 (Niemelä, pers. obs.) and only occurred on the main island of Aland in the 1999 samples. Leistus terminatus $(6.9 \mathrm{~mm}$, longwinged), $P$. atrorufus (8.6 mm, short-winged), Clivina fossor (6.0 mm, dimorphic) and Loricera pilicornis (7.1 mm, longwinged) occurred exclusively or predominantly on the main island, and have decreased in abundance since 1982. Pterostichus melanarius ( $14.7 \mathrm{~mm}$, dimorphic) has not been captured on the small islands, but has been quite abundant on the main island, in particular in 1999. Agonum livens ( $8.9 \mathrm{~mm}$, long-winged) is also confined to the main island. Pterostichus oblongopunctatus (10.9 mm, long-winged) has been collected from all the small islands, but is much less abundant there than on the main island.

Some species occurred both on the main island and on the small islands in more or less equal numbers. These include 
Figure 3 Non-metric multidimensional scaling ordination illustrating the separation between the main island and the small island sites, and between years. Each sampling year is connected with a line. Stress values, analysis of similarity (ANOSIM) $r$-statistic and $P$ values are also given. (A-E) (open circles) are the five sites sampled on the main island of Åland. (F-J) (closed triangles) are the five small island sites sampled [see Fig. 1 in Niemelä et al. (1985)], $82=1982$, $87=1987,88=1988,99=1999$.

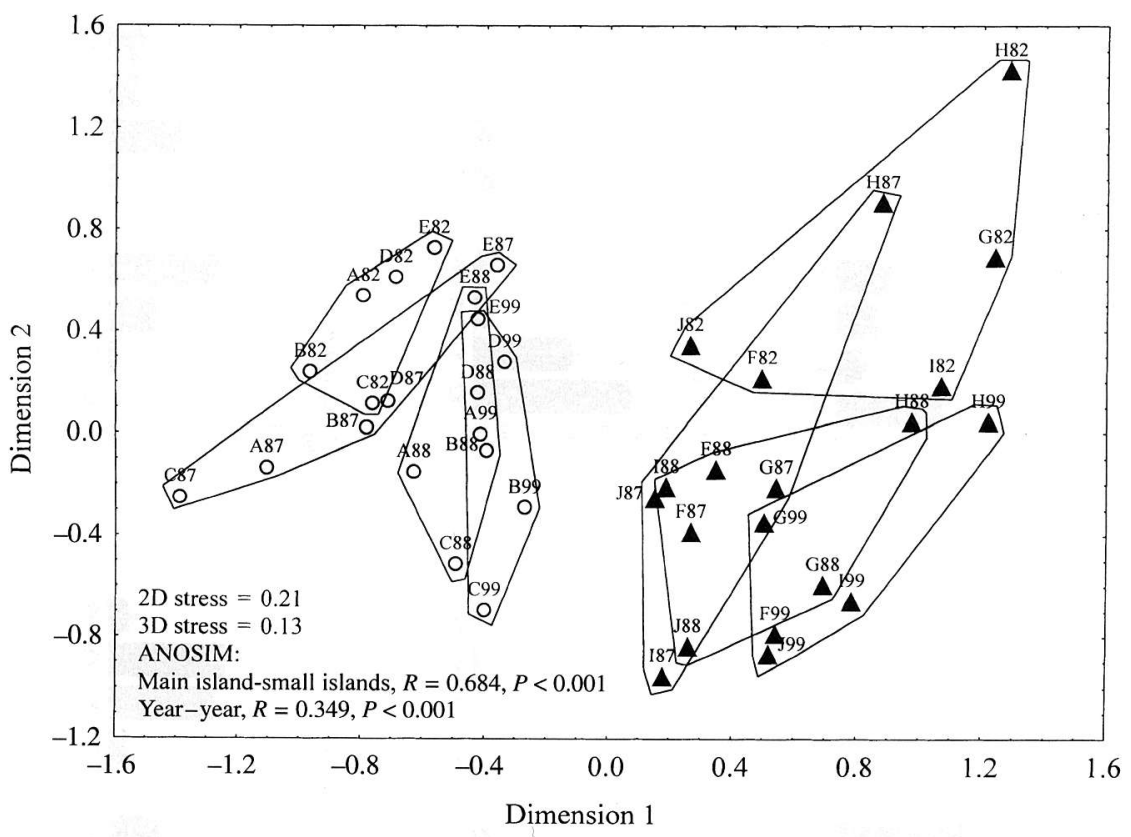

A. fuliginosum, P. nigrita, Calathus micropterus, A. obscurum and Trechus secalis.

Carabus hortensis $(24.8 \mathrm{~mm}$, short-winged), P. niger (17.5 mm, macropterous, but wings are probably not functionary; Lindroth, 1986) and Cychrus caraboides (16.3 mm, short-winged) were abundantly captured on the small islands in all 4 years sampled. Of particular interest here is that the last six species in Fig. 4 (those that are abundant on the small islands), are either short-winged or with non-functionary wings, and therefore have not been able to colonize these islands by flight.

\section{Carabid abundance, species richness and flight ability changes}

Flight ability had a significant effect on the incidence of carabid beetles in the Aland archipelago (Table 1; Fig. 5). Overall, significantly more individuals were captured on the main island of Aland, compared with the small islands. Also, significantly more flightless individuals were captured on both the main island and the small islands, compared with individuals capable of flight (Fig. 5a, b). In terms of rarefied species richness, there was no detectable significant difference between the main island and the small islands or between years (Table 1), although total number of species collected was higher on the main island compared with the small islands (Fig. 2).

Flight ability did have a significant effect on species occurrence on the islands. Although there were more species capable of flight on both the main island of Aland and the small islands (compared with the number of flightless species), there were more flightless species on the small islands than on the main island of Åland (Table 1; Fig. 5c, d). This result supports previous findings that small islands sample a higher proportion of flightless carabid species compared with the nearby mainland species pools ( $\mathrm{s}$ s, 1984; Kotze et al., 2000).

In absolute numbers, 33\% (ten of thirty) of the species collected on the small islands were short-winged, compared with $30 \%$ (twelve of forty) on the main island of Aland. Although this difference is not large, it is considerably higher than the proportion of short-winged species in the closest Finnish mainland province $[12 \%, 24 / 195$; see Lindroth $(1985,1986)]$. In other words, 63\% (twenty of thirty-two) of the species capable of flight, were collected on the small islands, while $83 \%$ (ten of twelve) of the flightless species collected, were collected on the small islands.

This result seems surprising as only $1.8 \%$ (18/996) of the carabid individuals, and $3.4 \%$ (three of eighty-seven) of the carabid species collected in sea drift on islands in the Eastern Gulf of Finland National Park between 1996 and 2000, were short-winged (Karjalainen, 2000) (Table 2).

\section{DISCUSSION}

\section{Year-to-year variation}

Both the main island of $\AA$ land and small island fauna changed between 1982 and 1999, but the distinction between the main island-small island fauna remained. Thus, it is possible to predict differences in carabid assemblage structure between the main island and the small islands based on 1 year of observation. This kind of ability to predict the pattern in ecological systems depends on the relationship between spatial and temporal scales of variation (Wiens, 1989). For example, studies conducted over a long time at fine spatial scales have low predictive powers, while studies conducted over larger spatial scales have higher 

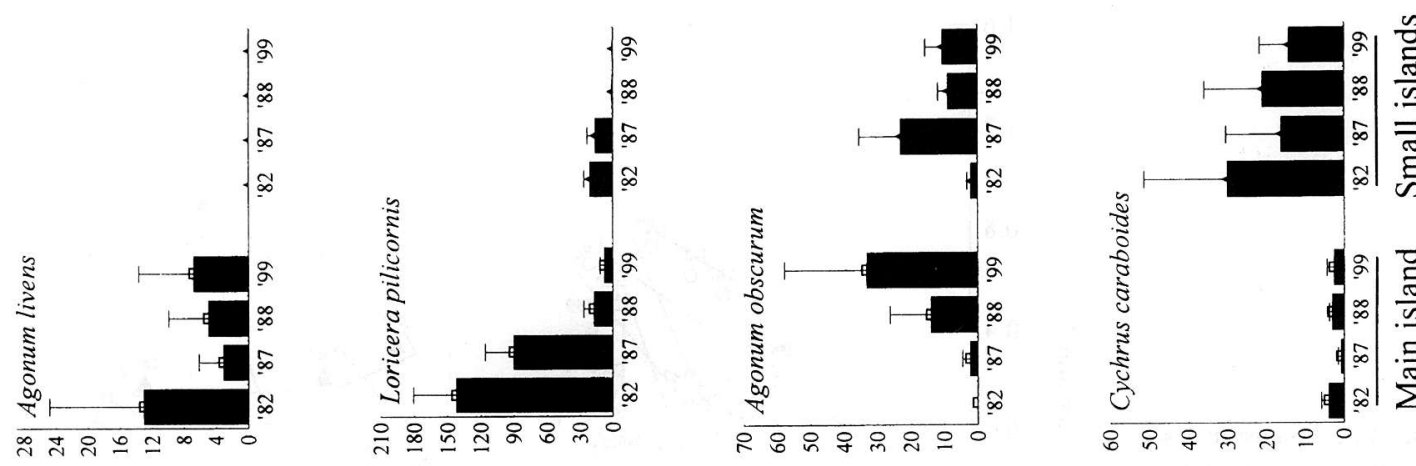

咅
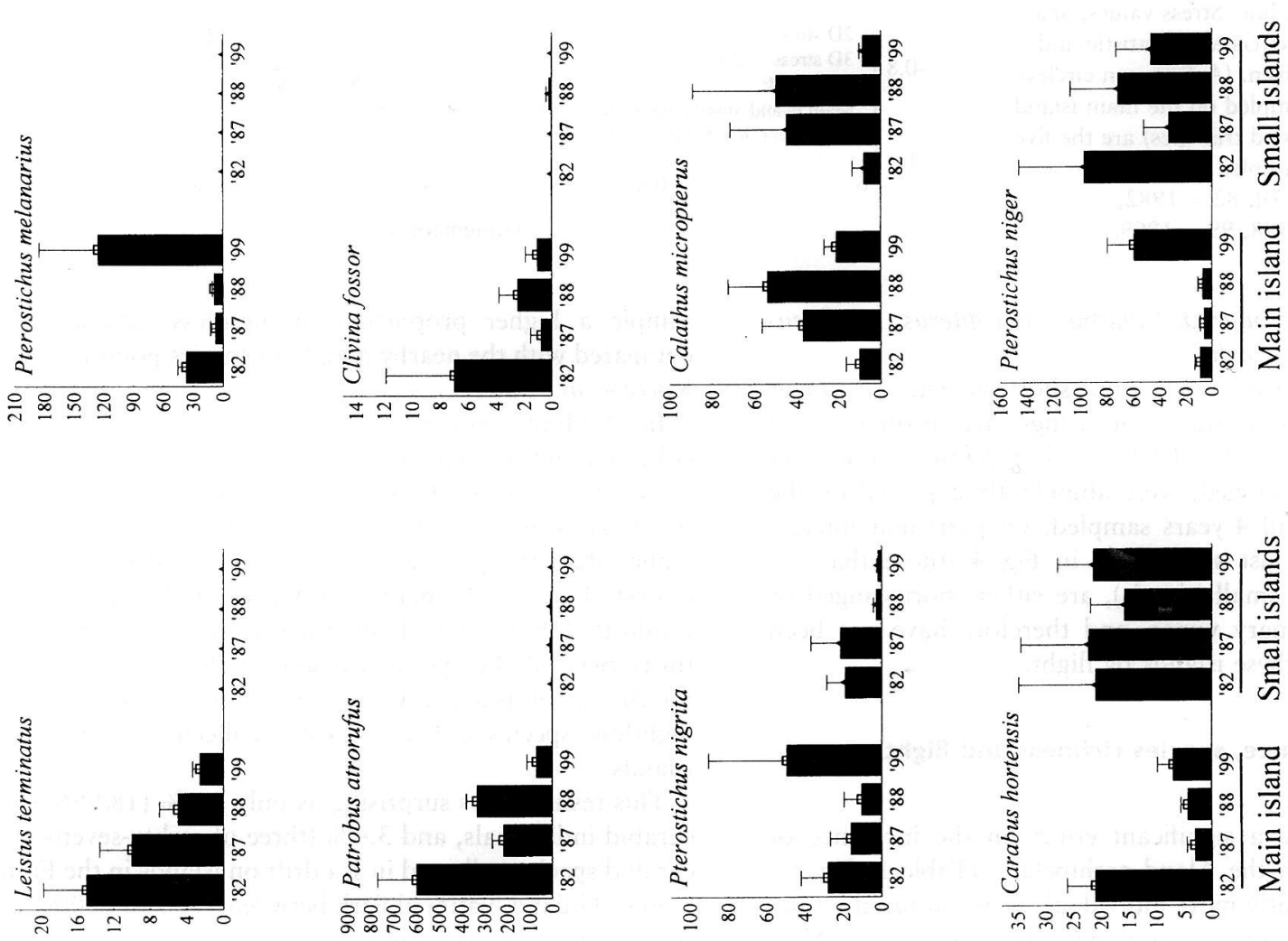

苞

के

क

돋

के

Е

过

岂 $\frac{\pi}{=}$

荡

들 들

है प्ष

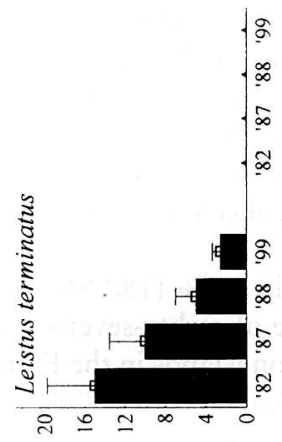

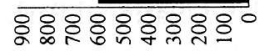
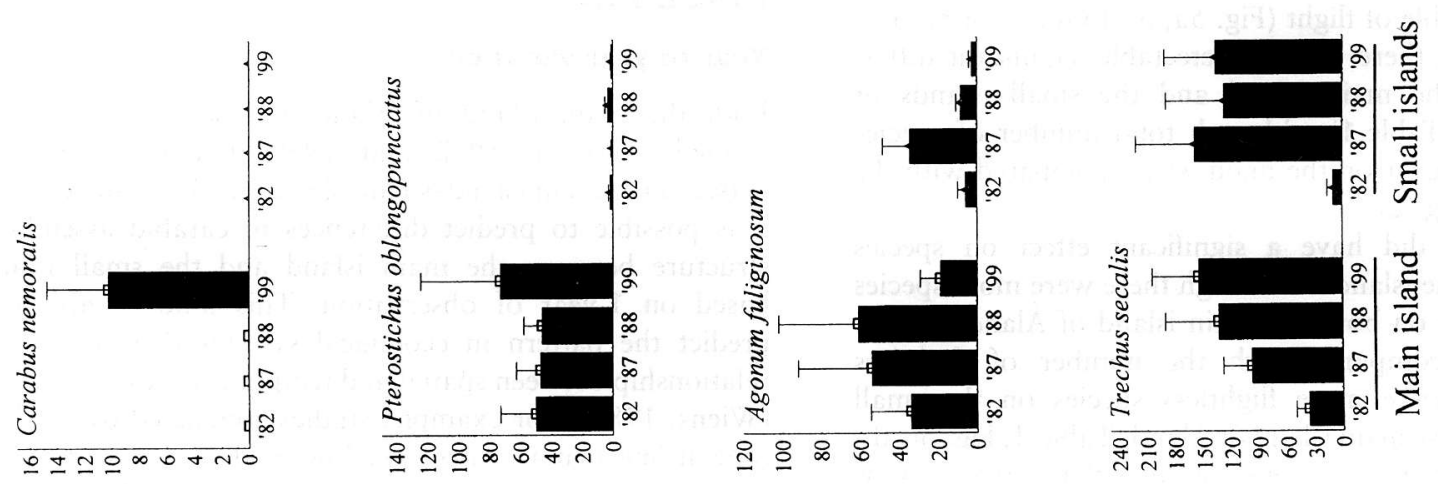

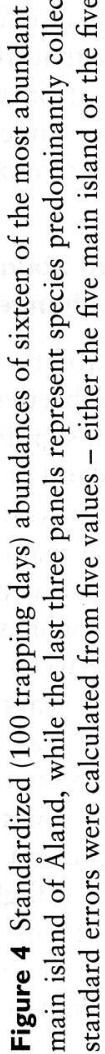


predictability. Our study showed that it is possible to predict carabid differences at the assemblage level, i.e. in each of the 4 years sampled the main island fauna was significantly different from the small island fauna. As expected, at the finer level of populations among small island or main island sites, this was not possible as abundance levels of individual species changed considerably between years.

The year-to-year variation in carabid assemblages may be caused by weather conditions. It has been suggested that macro-climatological factors are important in regulating carabid populations (Hengeveld, 1985; Desender, 1996), but it appears that climate alone is not responsible for the changes in the abundances of individual species on Åland. For example, three of the most abundant carabid species collected on the main island, P. atrorufus, L. pilicornis and
L. terminatus are associated with wet conditions (Lindroth, $1985,1986)$, but have decreased markedly in numbers since 1982. Yet, conditions have become wetter on the Alland islands since 1970 .

Forestry may be more important in influencing carabid numbers on the main island of Åland. For example, forestry is responsible for the draining of moist areas and clearcuts (Esseen et al., 1997). This 'drying up' of habitat may be responsible for the decline in numbers of wet-habitat species (see above), the increase in numbers of dry-habitat species (C. nemoralis and P. oblongopunctatus), and the increase in numbers of species associated with disturbed, human environments ( $P$. melanarius, Trechus secalis and $P$. niger). Indeed, forestry activity has been recorded in three of the five main island sites investigated.
Figure 5 Yearly standardized carabid abundance on the main island of Alland (a) and the small islands (b), and yearly rarefied carabid species richness on the main island of Aland (c) and the small islands (d). Carabid beetles were divided into those capable of flight (macropterous and dimorphic) and flightless species (brachypterous). The figure represents the three-way interactions in Table 1.
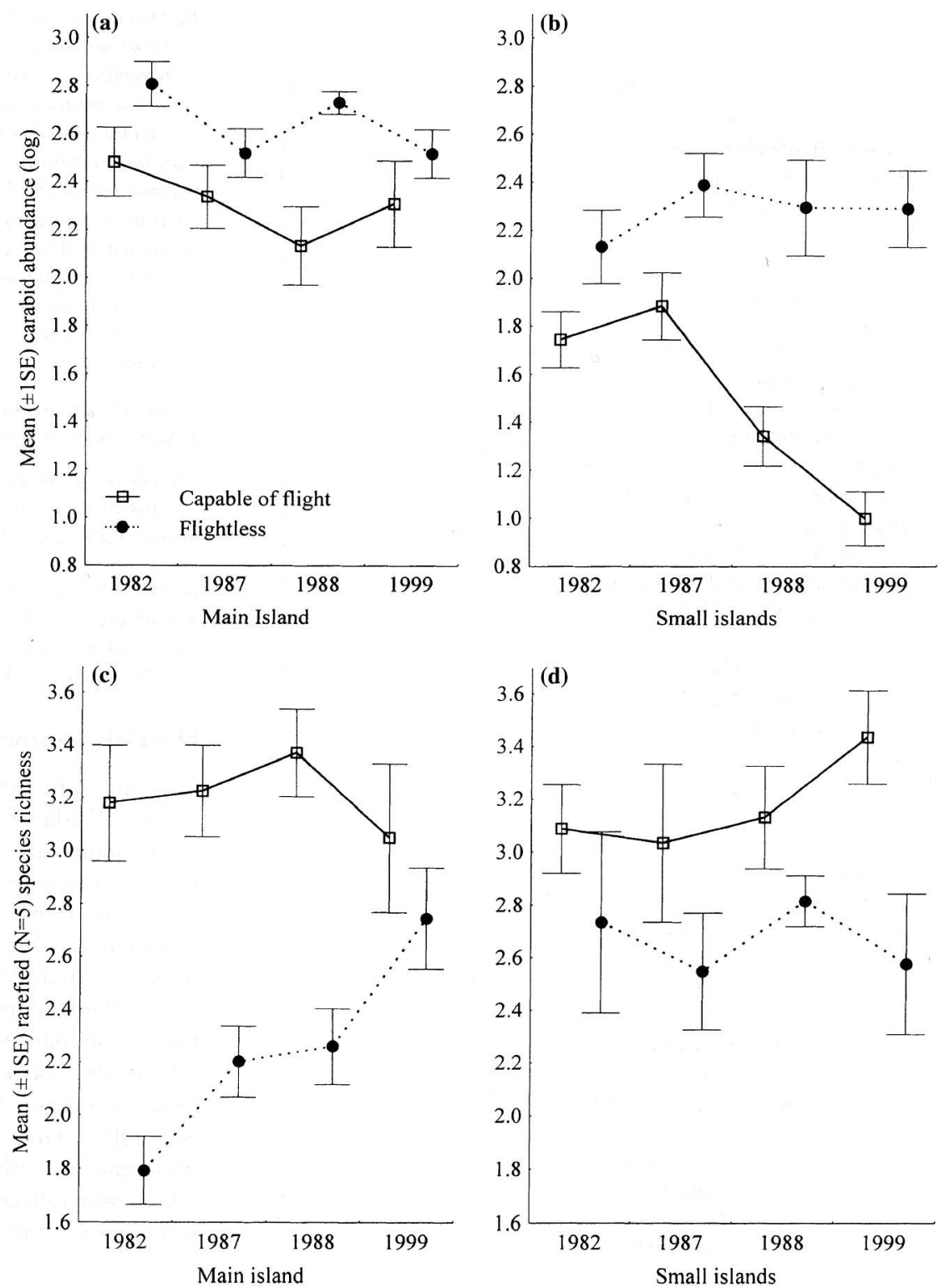
Table 2 Carabid beetles collected in sea drift in the Eastern Gulf of Finland National Park, from 1996 to 2000 (Karjalainen, 2000). Species are divided into a macropterous group (first sixty-five species), dimorphic group (next seventeen species), unknown wingform group (two species), and a brachypterous group (last three species)

Species n n

Acupalpus flavicollis (Sturm 1825) 14,16

A. meridianus (L. 1761) 2, 9, 12, 14, 16

A. parvulus (Sturm 1825) 2, 4, 9, 12, 13, 14, 15, 16

Agonum piceum (L. 1758) ${ }^{14,16}$

A. sexpunctatum (L. 1758) ${ }^{9}, 14$

A. thoreyi Dejean $1828^{9}, 13,14,15,18$

Amara aenea (Degeer 1774) 4, 13, 14

A. apricaria (Paykull 1790) ${ }^{3}$

A. aulica (Panzer 1797) ${ }^{14}$

A. bifrons (Gyllenhal 1810) ${ }^{14}$

A. brunnea (Gyllenhal 1810) 4, 15, 19

A. communis (Panzer 1797) 2, 9, 12, 13, 14, 16

A. famelica Zimmermann $1832^{2,}, 12,14,16$

A. familiaris (Duftschmid 1812) 2, 3, 4, 12, 14, 16

A. fulva (Müller 1776) 3, 9, 12, 13, 16

A. ingenua (Duftschmid 1812) ${ }^{12}$

A. lunicollis Schiødte $1837^{2,}, 4,9,13,14,16$

A. majuscula (Chaudoir 1850) 3, 8, 9, 12, 13

A. nitida Sturm $1825^{2,12,14}$

A. ovata (F. 1792) ${ }^{3}$

A. plebeja (Gyllenhal 1810) 2, 3, 9, 14, 16

A. praetermissa (Sahlberg 1827)

A. similata (Gyllenhal 1810) 2,14

A. tibialis (Paykull 1798) 2,14

Anchomenus dorsalis (Pontoppidan 1763) 12, 13

Anisodactylus binotatus (F. 1787) ${ }^{15}$

Asaphidion pallipes (Duftschmid 1812) ${ }^{12}$

Badister bullatus (Schrank 1798) ${ }^{2}$

B. dilatatus (Chaudoir 1837) ${ }^{14}$

B. peltatus (Panzer 1797) ${ }^{14,15}$

Bembidion articulatum (Panzer 1796) ${ }^{16}$

B. bruxellense Wesmaël $1835^{4,16}$

B. deletum (Audinet-Serville 1821) 12, 13, 14

B. doris (Panzer 1797) 4, 9, 12, 13, 14, 16

B. obliquum Sturm $1825^{9,12,14,16}$

B. pygmaeum (F. 1792) ${ }^{9}$

B. quadrimaculatum (L. 1761) 2, 4, 9, 12, 13, 14, 16

B. saxatile Gyllenhal $1827^{2,4}$, 9, 13, 16

Dromius fenestratus (F. 1794) ${ }^{2}$

D. schneideri Crotch $1871^{13}$

D. quadraticollis Morawitz 1862 2, 9, 14, 16

Dyschirius aeneus (Dejean 1825) ${ }^{4}$, 13, 14, 16

Elaphrus riparius (L. 1758) ${ }^{3}$

Harpalus affinis (Schrank 1781) 2, 3, 4, 12, 13, 14, 16

H. laevipes (Zetterstedt 1829) 2, 3, 12, 13, 14, 15, 16

H. latus (L. 1758) ${ }^{14}$

H. rubripes (Duftschmid 1812) 3, 9, 12, 16

H. rufipes (Degeer 1774) 3, 4, 12

Lebia chlorocephala (Hoffmann 1803) $)^{9}, 13,16$

Loricera pilicornis (F. 1775) 13, 14, 16

Microlestes minutulus (Goeze 1777) ${ }^{14}$

Ophonus nitidulus (Stephens 1828) ${ }^{3}$

O. rufibarbis (F. 1792) 2, 9

Panagaeus cruxmajor (L. 1758) 2,23
Table 2 continued

\begin{tabular}{|c|c|}
\hline Species & $n$ \\
\hline Perigona nigriceps (Dejean 1831$)^{12}$ & 1 \\
\hline Platynus livens (Gyllenhal 1810) $3,12,16$ & 7 \\
\hline Porotachys bisulcatus (Nicolai 1822$)^{12}$ & 1 \\
\hline Pterostichus cupreus (L. 1758) ${ }^{2,14}$ & 9 \\
\hline P. crenatus (Duftschmid 1812) $2,3,9,12,13,14,16$ & 16 \\
\hline P. niger (Schaller 1783$)^{14}$ & 1 \\
\hline P. oblongopunctatus (F. 1787) ${ }^{13,16}$ & 3 \\
\hline P. rhaeticus (Heer 1837) ${ }^{4}, 14,16$ & 7 \\
\hline P. versicolor (Sturm 1824) $3,5,9,12,13,15,16$ & 15 \\
\hline Stenolophus mixtus (Herbst 1784) 2, 3, 12, 14, 16 & 8 \\
\hline Trichocellus placidus (Gyllenhal 1827) & 35 \\
\hline Agonum fuliginosum (Panzer 1809) 2, 12, 14, 16 & 12 \\
\hline Bembidion gilvipes Sturm $1825^{14}$ & 1 \\
\hline B. guttula (F. 1792) $2,3,4,12,13,14,16$ & 273 \\
\hline B. lampros (Herbst 1784) $4,9,12,13,14,16$ & 15 \\
\hline B. properans (Stephens 1828$)^{14}$ & 2 \\
\hline B. transparens (Gebler 1829) $4,9,12,13,14,16$ & 10 \\
\hline Bradycellus caucasicus (Chaudoir 1846) ${ }^{12}$ & 3 \\
\hline Calathus erratus (Sahlberg 1827) ${ }^{3}$ & 1 \\
\hline C. melanocephalus (L. 1758) $2,3,9,13,14,16$ & 8 \\
\hline Carabus clathratus L. $1761^{4}$ & 1 \\
\hline Clivina fossor (L. 1758) $2,7,9,13,14,16$ & 12 \\
\hline Notiophilus biguttatus (F. 1779) $)^{9,13}$ & 3 \\
\hline N. palustris (Duftschmid 1812) (16 $^{16}$ & 1 \\
\hline Pterostichus diligens (Sturm 1824) ${ }^{7}, 14$ & 2 \\
\hline P. minor (Gyllenhal 1827) $2,3,9,12,13,14,16$ & 15 \\
\hline P. strenuus (Panzer 1797) $2,3,4,5,7,9,12,13,14,16$ & 37 \\
\hline Syntomus truncatellus (L. 1761) 3, 9, 12, 14 & 6 \\
\hline ? Harpalus brachypus (Dejean) ${ }^{9}$ & 1 \\
\hline ? Nebria rufescens (Strøm 1768) ${ }^{13}$ & 1 \\
\hline Dyschirius globosus (Herbst 1784) 2, 9, 12, 13, 14 & 15 \\
\hline Leistus ferrugineus (L. 1758) & 1 \\
\hline Stomis pumicatus (Panzer 1796) ${ }^{12}$ & 2 \\
\hline
\end{tabular}

Island abbreviations: 2-Mustaviiri, 3-Pitkäviiri, 4-Ristisaari, 5-Vaihkari, 7-Vähä Eteläkari, 8-Eteläkari, 9-Kilpisaari, 12-Koivuluoto, 13-Rääntiö, 14-Ulkotammio, 15-Varis, 16-Lanskeri, 17-Majakartti, 18-Kivikartti, 19-Suuri-Pisi, 23-Huovari.

\section{Main island-small island comparisons}

Carabid fauna differed significantly between the main island and small island sites. First, although there was no statistically significant difference in rarefied species richness between the main and small islands (see also Niemelä et al., 1985), in terms of absolute numbers more species were collected on the main island (forty-one species) compared with the small islands (thirty-one species). The non-significant difference in rarefied species richness is because of the lower abundances on the small islands, indicating that the relationship between abundance and species richness was quite similar on the main island and on the small islands. Secondly, many of the abundant species showed distinct preference for either the main island or the small island sites, which was reflected in that the main and small island sites were significantly different in terms of carabid assemblage structure. 
Area per se is likely to account for the differences in species richness between the islands (Niemelä et al., 1985). The main island of Aland is about 90,000 ha in size and supports a diverse number of habitats compared with the small islands (8-29 ha) sampled. Although sampling was only carried out in moist, spruce-dominated lush forest patches on both the main and small islands [thereby excluding the habitat diversity hypothesis for increased species richness, see Ås et al. (1997)], main island sites were in close proximity to many different habitat types from where tourist and dispersing species penetrate the study sites accidentally (Niemelä, 1988; Desender, 1996). This is evident from the high proportion (32\%, thirteen of forty-one) of species collected at the main island sites during one of the 4 years only (Appendix 1). Although the percentage for single year incidences on the small islands was the same $(32 \%$, ten of thirty-one), all of these ten species had the potential for flight, i.e. were either macropterous or dimorphic, while four of the thirteen main island species were brachypterous (C. glabratus, C. nemoralis, C. violaceus and C. fuscipes). This result suggests that tourist species of all dispersal abilities occasionally occur in main island forest sites, while most tourists to the small islands are capable of flight.

Apart from the obvious size difference between the main island of Aland and the small islands, human land use, in particular forestry, may also be responsible for differences seen in carabid assemblage structure between these islands. Forestry is practised on the main island, but not on the small islands, and combined with the low degree of other human disturbances on the small islands may at least in part explain why C. hortensis, P. niger and Cychrus caraboides are common on these islands. As these species do not possess functional flight apparatuses, they are considered to be poor dispersers, but at the same time relatively good survivors (Turin \& Den Boer, 1988). Island and mainland fauna are also expected to be quite different because of a unique combination of climatic, geological and topographical factors on the islands (Ås et al., 1997).

\section{Colonization success}

Carabid species of smaller body size and long wings are more successful in colonizing Dutch polder islands (Ranta \& Ås, 1982). On the contrary, in our study the small islands had a higher proportion and number of short-winged species compared with the main island of Aland, and many of the abundant species on the small islands, apart from being short-winged, are also large (see also Niemelä et al., 1985). A similar pattern has been found for other studies on islands in the Baltic Sea (Ås, 1984; Niemelä et al., 1988; Kotze et al., 2000).

Although the wing-form patterns of this study are in agreement with those of Ås (1984) and Kotze et al. (2000), our study eliminates an important confounding aspect present in these studies. Both previous studies tested for differences in proportions of wing form between islands and the closest mainland province. This comparison is problematic because not only were the mainland fauna collected over many more years compared with the island samples, but also because the mainland sites consist of many more habitat types than the island sites sampled. For example, very few streams occur on Baltic islands, excluding many Bembidion species. This riparian genus of long-winged or wing dimorphic species, is the largest carabid genus in Fennoscandia (Lindroth, 1985, 1986), and their absence in island samples may seriously influence this wing-form comparison.

Our study compared carabid beetles in similar habitat types between the main island of Alland and the small islands, thereby eliminating the confounding effects of habitat diversity introduced by comparing small islands with a mainland. Although absolute proportions of shortwinged species were quite similar between the main island and the small islands ( 30 and $33 \%$, respectively), small islands were characterized by more short-winged species, compared to the main island, and that these short-winged species were abundant on the small islands (Figs 4 and 5).

The obvious questions are how these short-winged species disperse to small islands in the Baltic Sea, and why they appear to be more successful than long-winged species, once on these islands. It appears that for most taxa, island colonization is quite easy because of short inter-island distances in the Baltic (Järvinen \& Ranta, 1987) and because salinity is low (Ås, 1984). Carabids can survive up to 5 days in brackish water without adverse effects on fertility (Palmén, 1944) during which time they can drift up to $10 \mathrm{~km}$ (Ås, 1984). Short-winged carabids can therefore easily reach most islands in the Baltic Sea. Once on these islands, short-winged species seem more successful in establishing viable populations, probably because they (1) do not use energy for developing wing muscles and wings, and therefore have more resources available for immediate reproduction (Ås, 1984; Lövei \& Sunderland, 1996), (2) use less energy getting to the islands (drifting vs. flying), and (3) stand a lower risk of being repeatedly blown off of the islands ( ̊s, 1984).

The argument presented above seems reasonable, but needs systematic, empirical investigation, in particular (1) do carabid individuals survive drifting from island to island, and what is the volume of drift-beetles reaching island shores, (2) what is the proportion of winged to wingless species in drift material, (3) are short-winged species at an advantage when colonizing new habitat? To answer points (1) and (2) Karjalainen (2000) collected drift carabids on island shores in the Eastern Gulf of Finland National Park. $\mathrm{He}$ found that very few carabid individuals $(1.8 \%)$ and species $(3.4 \%)$ collected were short-winged. These findings suggest that very few short-winged carabids reach these islands, but that those who do are successful in establishing populations (point ' 3 ' above).

Here is clearly potential for further research (see also Niemelä et al., 1985). For example, it has been suggested that short-winged species, being poorly dispersing species, are slow immigrants, but at the same time relatively good survivors, good competitors for resources and have short pre-oviposition periods, leading to greater egg production at the onset of reproductive life (As, 1984; Turin \& Den 
Boer, 1988; Spence, 1989; Roff, 1990; Roff \& Fairbairn, 1991; Spence \& Andersen, 1994). Alternatively, it is also known that certain carabid beetles, and other insects, capable of flight are able to re-absorb their flight muscles after dispersal and before reproduction, potentially increasing their colonization success (Robertson, 1998; Desender, 2000), and that some long-winged carabid females produce more eggs and over a longer period of time (Aukema, 1991).

\section{ACKNOWLEDGMENTS}

We sincerely thank Seppo Karjalainen for making available data collected between 1996 and 2000 from the Eastern Gulf of Finland National Park. Two anonymous referees provided valuable comments to an earlier draft of this manuscript.

\section{REFERENCES}

Ås, S. (1984) To fly or not to fly? Colonization of Baltic islands by winged and wingless carabid beetles. Journal of Biogeography, 11, 413-426.

Ås, S., Bengtsson, J. \& Ebenhard, T. (1997) Archipelagoes and theories of insularity. Ecological Bulletins, 46, 88-116.

Aukema, B. (1991) Fecundity in relation to wing-morph of three closely related species of the melanocephalus group of the genus Calathus (Coleoptera: Carabidae). Oecologia, 87, 118-126.

Baars, M. \& Van Dijk, ThS. (1984a) Population dynamics of two carabid beetles at a Dutch heathland. I. Subpopulation fluctuations in relation to weather and dispersal. Journal of Animal Ecology, 53, 375-388.

Baars, M. \& Van Dijk, ThS. (1984b) Population dynamics of two carabid beetles at a Dutch heathland. II. Egg production and survival in relation to density. Journal of Animal Ecology, 53, 389-400.

Clarke, K.R. (1993) Non-parametric multivariate analyses of changes in community structure. Australian Journal of Ecology, 18, 117-143.

Clarke, K.R. \& Green, R.H. (1988) Statistical design and analysis for a 'biological effects' study. Marine Ecology Progress Series, 46, 213-226.

Colwell, R.K. \& Coddington, J.A. (1994) Estimating terrestrial biodiversity through extrapolation. Philosophical Transactions of the Royal Society of London B, 345, 101-118.

Den Boer, P. (1981) On the survival of populations in a heterogeneous and variable environment. Oecologia, 50, 39-53.

Desender, K.R.C. (1996) Diversity and dynamics of coastal dune carabids. Annales Zoologici Fennici, 33, 65-75.

Desender, K. (2000) Flight muscle development and dispersal in the life cycle of carabid beetles: patterns and processes. Entomologie, 70, 13-31.

Di Castri, F., Vernhes, J.R. \& Younès, T. (1992) Inventorying and monitoring biodiversity: a proposal for an international network. Biology International, 27, 1-27.

Esseen, P.-A., Ehnström, B., Ericson, L. \& Sjöberg, K. (1997) Boreal forests. Ecological Bulletins, 46, 16-47.
Haila, Y. (1990) Toward an ecological definition of an island: a northwest European perspective. Journal of Biogeography, $17,561-568$.

Hengeveld, R. (1985) Dynamics of Dutch beetle species during the twentieth century (Coleoptera, Carabidae). Journal of Biogeography, 12, 389-411.

Järvinen, O. \& Ranta, E. (1987) Patterns and processes in species assemblages on Northern Baltic islands. Annales Zoologici Fennici, 24, 249-266.

Karjalainen, S. (2000) A beetle monitoring in the eastern Gulf of Finland National Park in 1996-2000. Finnish Forest and Park Service, Natural Heritage Service, Southern Finland.

Kotze, D.J., Niemelä, J. \& Nieminen, M. (2000) Colonization success of carabid beetles on Baltic islands. Journal of Biogeography, 27, 807-819.

Lenski, R.E. (1982) Effects of forest cutting on two Carabus species: evidence for competition for food. Ecology, 63, 1211-1217.

Lenski, R.E. (1984) Food limitation and competition: a field experiment with two Carabus species. Journal of Animal Ecology, 53, 203-216.

Lindroth, C.H. (1985) The Carabidae (Coleoptera) of Fennoscandia and Denmark. Fauna Entomologica Scandinavica, Vol. 15, part 1, 1-225. Scandinavian Science Press Ltd, Copenhagen.

Lindroth, C.H. (1986) The Carabidae (Coleoptera) of Fennoscandia and Denmark. Fauna Entomologica Scandinavica, Vol. 15, part 2, 233-497. Scandinavian Science Press Ltd, Copenhagen.

Loreau, M. (1986) Niche differentiation and community organization in forest carabid beetles. Carabid beetles, their adaptations and dynamics (eds P.J. Den Boer, M.L. Luff, D. Mossakowski and F. Weber), pp. 465-487. Fischer, Stuttgart.

Lövei, G.L. \& Sunderland, K.D. (1996) Ecology and behavior of ground beetles (Coleoptera: Carabidae). Annual Review of Entomology, 41, 231-256.

Magurran, A.E. (1988) Ecological diversity and its measurement. Princeton University Press, Princeton.

Meteorological Yearbook of Finland (Suomen Meteorologinen Vuosikirja) (1968-99) Climatological Data (1968-99), Vols. 68-99. The Finnish Meteorological Institute, Helsinki, Finland.

Niemelä, J. (1988) Habitat occupancy of carabid beetles on small islands and the adjacent Aland mainland, SW Finland. Annales Zoologici Fennici, 25, 121-131.

Niemelä, J. (1992) Distribution of carabid beetles in the Aland archipelago, SW Finland (Coleoptera, Carabidae). The biogeography of Carabidae of mountains and islands (eds G. Noonan, G. Ball and N. Stork), pp. 175-186. Intercept Publications, Andover.

Niemelä, J. (1993) Interspecific competition in ground-beetle assemblages (Carabidae): what have we learned? Oikos, 66, 325-335.

Niemelä, J. (1996) From systematics to conservation - carabidologists do it all. Annales Zoologici Fennici, 33, 1-4.

Niemelä, J., Haila, Y. \& Halme, E. (1988) Carabid beetles on isolated Baltic islands and on the adjacent Åland mainland: variation in colonization success. Annales Zoologici Fennici, $25,133-143$. 
Niemelä, J., Ranta, E. \& Haila, Y. (1985) Carabid beetles in lush forest patches on the Aland Islands, south-west Finland: an island-mainland comparison. Journal of Biogeography, 12, 109-120.

Nieminen, M. \& Hanski, I. (1998) Metapopulations of moths on islands: a test of two contrasting models. Journal of Animal Ecology, 67, 149-160.

Palmén, E. (1944) Die Anemohydrochore Ausbreitung der Insekten als Zoogeographischer Faktor. Annales Zoologici Societatis Zoologicae Botanicae Fennicae Vanamo, 10, 1-262.

Price, P.W. (1984) Insect ecology. John Wiley \& Sons, New York.

Ranta, E. \& Ås, S. (1982) Non-random colonization of habitat islands by carabid beetles. Annales Zoologici Fennici, 19, 175-181.

Robertson, I.C. (1998) Flight muscle changes in male pine engraver beetles during reproduction: the effects of body size, mating status and breeding failure. Physiological Entomology, 23, 75-80.

Roff, D.A. (1990) The evolution of flightlessness in insects. Ecological Monographs, 60, 389-421.

Roff, D.A. \& Fairbairn, D.J. (1991) Wing dimorphisms and the evolution of migratory polymorphisms among the Insecta. American Zoologists, 31, 243-251.

Saccheri, I., Kuussaari, M., Kankare, M., Vikman, P., Fortelius, W. \& Hanski, I. (1998) Inbreeding and extinction in a butterfly metapopulation. Nature, 392, 491-494.

Simberloff, D.S. (1978) Use of rarefaction and related methods in ecology. Biology data in water pollution assessment: quantitative and statistical analysis (eds K.L. Dickson, J. Garins, Jr and R.J. Livingston), pp. 150-165. American Society for Testing and Materials, STP 652 West Conshohocken, PA, USA.

Spence, J.R. (1989) The habitat templet and life history strategies of pond skaters (Heteroptera: Gerridae): reproduc- tive potential, phenology, and wing dimorphism. Canadian Journal of Zoology, 67, 2432-2447.

Spence, J.R. \& Andersen, N.M. (1994) Biology of water striders: interactions between systematics and ecology. Annual Review of Entomology, 39, 101-128.

Thiele, H.U. (1977) Carabid beetles in their environment. Springer-Verlag, Berlin.

Turin, H. \& Den Boer, P.J. (1988) Changes in the distribution of carabid beetles in The Netherlands since 1880 . II. Isolation of habitats and long-term time trends in the occurrence of carabid species with different powers of dispersal (Coleoptera, Carabidae). Biology Conservation, 44, 179-200.

Wiens, J.A. (1989) Spatial scaling in ecology. Functional Ecology, 3, 385-397.

Wolda, H. (1978) Fluctuations in abundance of tropical insects. American Naturalist, 112, 1017-1045.

Wolda, H. (1992) Trends in abundance of tropical forest insects. Oecologia, 89, 47-52.

\section{BIOSKETCHES}

Dr Johan Kotze works as a postdoctoral scientist in the Department of Ecology and Systematics at the University of Helsinki, Finland. For the last 3 years, he has been working on carabid beetles on islands, in urban environments, and as a model group in macroecological studies.

Professor Jari Niemelä teaches in the Department of Ecology and Systematics at the University of Helsinki, Finland. His research interests include island biogeography, urban ecology and carabid beetles. 
Appendix I Carabids captured on the main island of Aland and adjacent islands in 1982, 1987, 1988 and 1999

\begin{tabular}{|c|c|c|c|c|c|c|c|c|c|c|}
\hline \multirow[b]{2}{*}{ Species } & \multirow[b]{2}{*}{ Body size } & \multirow[b]{2}{*}{ Wing form } & \multicolumn{4}{|c|}{ Main island sites } & \multicolumn{4}{|c|}{ Small island sites } \\
\hline & & & 1982 & 1987 & 1988 & 1999 & 1982 & 1987 & 1988 & 1999 \\
\hline Agonum fuliginosum (Panzer 1809) & 6.5 & $\mathrm{~d}$ & 34 & 70 & 296 & 89 & 6 & 45 & 41 & 13 \\
\hline A. gracile Sturm 1824 & 6.6 & $\mathrm{~m}$ & 12 & & & & 6 & & & \\
\hline A. livens (Gyllenhal 1810)† & 8.9 & $\mathrm{~m}$ & 13 & 4 & 24 & 32 & & & & \\
\hline A. obscurum (Herbst 1784) & 5.7 & $\mathrm{~B}$ & & 3 & 68 & 156 & 2 & 30 & 43 & 49 \\
\hline A. thoreyi Dejean $1828^{*}$ & 6.9 & $\mathrm{~m}$ & & & & & 1 & & & \\
\hline Agonum speciest & & & & & 1 & & & & & \\
\hline Amara brunnea (Gyllenhal 1810) & 5.9 & $\mathrm{~m}$ & 1 & 2 & 17 & 3 & 3 & 2 & 15 & 9 \\
\hline A. communis (Panzer 1797) & 6.4 & $\mathrm{~m}$ & & & & 2 & & & 3 & 1 \\
\hline Amara species* & & & & & & & & & 1 & \\
\hline Badister bullatus (Schrank 1798)* & 5.6 & $\mathrm{~m}$ & & & & & & 1 & 1 & \\
\hline Bembidion guttula (F. 1792) & 3.1 & d & 1 & 3 & 2 & 1 & & & & \\
\hline B. lampros (Herbst 1784)† & 3.6 & $\mathrm{~d}$ & & & & 1 & & & & \\
\hline Calathus fuscipes (Goeze 1777) $\dagger$ & 12.0 & B & & & & 1 & & & & \\
\hline C. melanocephalus (L. 1758) $\dagger$ & 7.3 & $\mathrm{~d}$ & & 1 & 1 & & & & & \\
\hline C. micropterus (Duftschmid 1812) & 7.6 & B & 10 & 48 & 261 & 99 & 8 & 58 & 241 & 41 \\
\hline Carabus glabratus Paykull 1790 & 25.7 & B & & & 2 & & & 1 & 5 & \\
\hline C. hortensis L. 1758 & 24.8 & $\mathrm{~B}$ & 21 & 4 & 21 & 33 & 21 & 29 & 77 & 101 \\
\hline C. nemoralis Müller $1764 \dagger$ & 23.9 & $\mathrm{~B}$ & & & & 48 & & & & \\
\hline C. violaceus L. 1758 & 24.5 & $\mathrm{~B}$ & & & & 8 & 2 & & & 23 \\
\hline Clivina fossor (L. 1758) & 6.0 & $\mathrm{~d}$ & 7 & 1 & 12 & 5 & & & 1 & \\
\hline Cychrus caraboides (L. 1758) & 16.3 & $\mathrm{~B}$ & 4 & 1 & 15 & 13 & 30 & 21 & 102 & 67 \\
\hline Elaphrus cupreus Duftschmid 1812 & 8.7 & $\mathrm{~m}$ & 1 & & 5 & & & & 1 & \\
\hline E. riparius (L. 1758) & 7.2 & $\mathrm{~m}$ & & 1 & & & & 2 & & \\
\hline Harpalus latus (L. 1758) $\dagger$ & 9.5 & $\mathrm{~m}$ & & 1 & & & & & & \\
\hline H. quadripunctatus Dejean 1829 & 10.7 & $\mathrm{~m}$ & 2 & 3 & 8 & 19 & & 1 & 2 & \\
\hline Leistus terminatus (Hellwig 1793) & 6.9 & $\mathrm{~m}$ & 15 & 13 & 24 & 12 & & & & \\
\hline Loricera pilicornis (F. 1775) & 7.1 & $\mathrm{~m}$ & 142 & 117 & 84 & 37 & 21 & 21 & 4 & 2 \\
\hline Notiophilus aquaticus (L., 1758) $\dagger$ & 5.2 & $\mathrm{~d}$ & & 1 & & & & & & \\
\hline N. biguttatus (F. 1779) & 5.5 & $\mathrm{~d}$ & 3 & 10 & 29 & 9 & & 5 & 5 & 4 \\
\hline N. palustris (Duftschmid 1812) $\dagger$ & 5.5 & $\mathrm{~d}$ & & & 1 & & & & & \\
\hline Patrobus assimilis Chaudoir 1844 & 8.9 & B & 33 & 3 & 3 & 15 & 10 & & 1 & \\
\hline P. atrorufus (Ström 1768) & 8.6 & $\mathrm{~B}$ & 597 & 280 & 1604 & 329 & 2 & 9 & 30 & 4 \\
\hline Pterostichus cupreus (L. 1758)* & 12.1 & $\mathrm{~m}$ & & & & & & & & 1 \\
\hline P. diligens (Sturm 1824) & 6.0 & $\mathrm{~d}$ & & & 2 & 18 & & 3 & & \\
\hline P. melanarius (Illiger 1798) $\dagger$ & 14.7 & $\mathrm{~d}$ & 37 & 10 & 44 & 590 & & & & \\
\hline P. minor (Gyllenhal 1827)* & 7.7 & $\mathrm{~d}$ & & & & & & 4 & & \\
\hline P. niger (Schaller 1783) & 17.5 & $\mathrm{~m} \S$ & 9 & 8 & 35 & 279 & 97 & 43 & 347 & 220 \\
\hline P. nigrita (Paykull 1790) & 10.6 & $\mathrm{~m}$ & 28 & 21 & 51 & 232 & 19 & 28 & 14 & 9 \\
\hline P. oblongopunctatus (F. 1787) & 10.9 & $\mathrm{~m}$ & 50 & 61 & 223 & 344 & 2 & 1 & 17 & 6 \\
\hline P. strenuus (Panzer 1797) & 6.6 & $\mathrm{~d}$ & 7 & 19 & 29 & 42 & 1 & 9 & 16 & 7 \\
\hline Synuchus vivalis (Illiger 1798) $\dagger$ & 7.1 & $\mathrm{~d}$ & & & 1 & 1 & & & & \\
\hline Trechus quadristriatus (Schrank 1791) $\dagger$ & 3.7 & $\mathrm{~m}$ & & & 15 & & & & & \\
\hline T. rivularis (Gyllenhal 1810) $\dagger$ & 4.6 & $\mathrm{~d}$ & 1 & 3 & & 9 & & & & \\
\hline T. rubens (F. 1792) & 5.7 & $\mathrm{~m}$ & & & 1 & 9 & & 1 & & \\
\hline T. secalis (Paykull 1790) & 3.7 & $\mathrm{~B}$ & 37 & 127 & 646 & 726 & 10 & 206 & 616 & 641 \\
\hline Trichocellus placidus (Gyllenhal 1827) & 4.7 & $\mathrm{~m}$ & 4 & 2 & 2 & 5 & 4 & & & 1 \\
\hline Total number of individuals & & & 1069 & 817 & 3527 & 3167 & 245 & 520 & 1583 & 1199 \\
\hline Total number of species & & & 24 & 27 & 31 & 31 & 18 & 21 & 22 & 18 \\
\hline
\end{tabular}

$\uparrow$ Species collected on the main island of Aland only.

"Species collected on the small islands only.

\$Although Pterostichus niger is classified as having long wings (macropterous), they are probably non functional (see Lindroth, 1986). 